\title{
Long-term changes in fish assemblage following the impoundments of the Three Gorges Reservoir in Hejiang, a protected reach of the upper Yangtze River
}

\author{
F. Liu(1),(2),(3) , J. Wang ${ }^{(1),(3), \star}$, W. Cao ${ }^{(1),(3)}$
}

Received August 17, 2012

Revised January 5, 2013

Accepted January 6, 2013

\section{ABSTRACT}

Key-words: The construction of the Three Gorges Reservoir (TGR) has seriously affish assemblage, fected the fish assemblage in the impounded reaches. However, fish long-term changes, the Three Gorges Reservoir, the upper Yangtze River assemblage changes in the riverine zone remain poorly documented. In order to explore how upstream fish assemblage has responded to the successive impoundments of the TGR, fish investigations were conducted biannually in Hejiang, a protected reach of the upper Yangtze River, during the period from 1997 to 2011. Multivariate analysis revealed significant temporal differences in fish assemblage following the impoundments of the TGR. Prior to the impoundments, the fish assemblage appeared to be very diversified and very even. Immediately after the first and the second impoundment, the lotic species, such as Coreius guichenoti, Rhinogobio ventralis, Rhinogobio cylindricus and Coreius heterodon, became evidently dominant, due to their upstream migrations from the reservoir. However, two years after the third impoundment, the lotic species decreased dramatically, while lentic Hypophthalmichthys molitrix and Pelteobagrus vachelli became the new dominant species. Based on this and other studies, we can see the habitats of the riverine fish in the upper Yangtze River have been shrunk seriously because of the impoundments of the TGR. The cascade hydropower development in the lower Jinsha River will pose an accumulative effect on the aquatic environment in the mainstream of the upper Yangtze River. Free-flowing tributaries, such as the Chishui River, will play more important roles in fish conservation.

RÉSUMÉ

Changements à long terme dans les assemblages de poissons en Hejiang, un bief protégé de la haute rivière Yangtsé, après mise en service du Barrage des Trois Gorges

Mots-clés : assemblage de poissons,
La construction du réservoir des Trois Gorges (TGR) a sérieusement affecté l'assemblage de poissons dans les biefs aménagés. Cependant, les changements d'assemblage de poissons dans la zone lentique amont restent mal documentés. Afin d'explorer la façon dont les assemblages de poissons en amont ont répondu aux remplissages successifs du TGR, des investigations piscicoles ont été menées deux fois par an dans Hejiang, un secteur protégé de la rivière Yangtsé amont, au

(1) Institute of Hydrobiology, Chinese Academy of Sciences, 7th southern road of East Lake, Wuhan, Hubei Province, 430072, P.R. China

(2) Graduate University of Chinese Academy of Science, Beijing, 100039, P.R. China

(3) Key Laboratory of Biodiversity and Conservation of Aquatic Organisms, Chinese Academy of Science, Wuhan, Hubei Province, 430072, P.R. China

* Corresponding author: wangjw@ihb.ac.cn 
changements

à long terme, réservoir

des Trois

Gorges, amont du fleuve Yangtsé cours de la période allant de 1997 à 2011. L'analyse multivariée a révélé d'importantes différences temporelles dans les peuplements de poissons après les remplissages successifs du TGR. Avant les retenues d'eau, l'assemblage de poissons semble être très diversifié et très équitable. Immédiatement après les mises en eau, les espèces lotiques, comme Coreius guichenoti, Rhinogobio ventralis, Rhinogobio cylindricus et Coreius heterodon sont devenues nettement dominantes, en raison de leur déplacement vers l'amont du réservoir. Cependant, deux ans après la troisième mise en eau, les espèces lotiques ont considérablement diminué, tandis que les espèces lentiques Hypophthalmichthys molitrix et Pelteobagrus vachelli sont devenues les nouvelles espèces dominantes. Sur la base de cette étude et d'autres, nous pouvons voir que les habitats des poissons fluviaux dans le cours supérieur du fleuve Yangtsé ont été réduits à cause des mises en eau du TGR. Le développement de l'hydroélectricité dans la partie inférieure du fleuve Jinsha causera un effet cumulatif pour l'environnement aquatique dans l'hydrologie de la rivière Yangtsé supérieure. Les affluents non aménagés, comme la rivière Chishui, joueront un rôle important dans la conservation des espèces de poisson.

\section{INTRODUCTION}

Aquatic biodiversity has declined sharply around the world and correspondingly, a large number of species are considered to be already extinguished or endangered (Moyle, 1992; Fu et al., 2003; Chen et al., 2009). Dam construction is regarded as one of the most dramatic anthropogenic factors that affect freshwater ecosystems (Bunn and Arthington, 2002). Dams and their associated impoundment can pose a great threat to biodiversity by altering water flow regimes, fragmenting habitats, modifying channel morphology and bed structure, changing water temperature and water quality, destroying reproductive environments, and blocking migration routes (Larinier, 2000). Notable upstream and downstream changes in fish assemblages, including species composition and relative abundance, have been observed after impoundment of reservoirs in many rivers (Erman, 1973; Winston, 1991; Gido et al., 2002; Jeffrey et al., 2003; Quinn and Kwak, 2003; Quist et al., 2005; Han et al., 2008; Johnson et al., 2008; Gao et al., 2010; Yang et al., 2012).

The Three Gorges Reservoir (TGR), located in the lower section of the upper Yangtze River, is the largest hydroelectric station in the world, with a capacity of $3.93 \times 10^{10} \mathrm{~m}^{3}$, water level $175 \mathrm{~m}$ above sea level (asl) and surface area of $1080 \mathrm{~km}^{2}$ (Huang et al., 2006). Closure of the TGR was completed in 1997 and the impoundment was implemented by three steps. The first impoundment was conducted on June 2003 and raised the water level from $95 \mathrm{~m}$ asl to $135 \mathrm{~m}$ asl. The second impoundment was conducted in September 2006, which resulted in a reservoir water level of $156 \mathrm{~m}$ asl. Experimental impoundment of the designed maximum water level, $175 \mathrm{~m}$ asl, was implemented in September 2008 and September 2009, and raised the water to about $173 \mathrm{~m}$ asl and $171 \mathrm{~m}$ asl, respectively. After two years of experiments, the water level of the TGR reached the designed water level in October 2010 for the first time, which represented the full operation of this reservoir. The upper reaches of the TGR have undergone fast and intense modifications after each impoundment because a lotic ecosystem has been suddenly transformed into a lentic environment. Ultimately, the portion of upper Yangtze River between Yichang City and Chongqing City, measured to be approximately $600 \mathrm{~km}$, has become known as the TGR. The impounding mode of the TGR provides a good opportunity to explore how fish assemblages have responded to these successive disturbances. Previous investigations have revealed evident and immediate fish assemblage changes in the lacustrine area and the transitional zone of the TGR (Wu et al., 2007; Gao et al., 2010; Yang et al., 2012). However, variations in fish assemblage in the riverine zone of the TGR remains poorly documented.

In this paper, based on data collected during the period from 1997 to 2011 in Hejiang, a protected upper reach of the upper Yangtze River, our objective was to explore long-term 


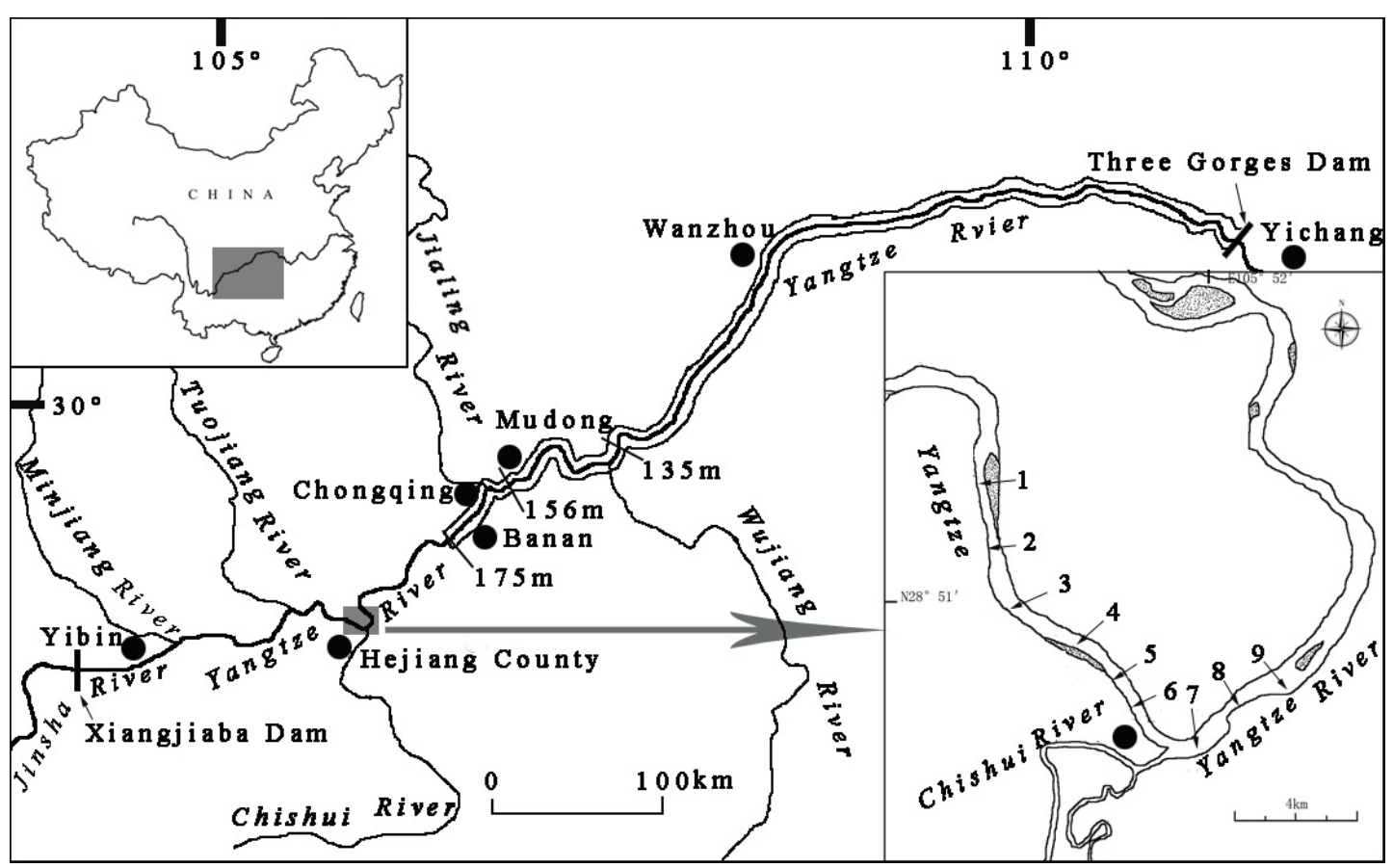

Figure 1

Study area and locations of the fish sampling sites (1-9).

temporal patterns of upstream fish assemblage properties following the successive impoundments of the TGR, including changes in species composition, relative abundance and size structure. We believe these findings can provide insight into basic ecological forces that structure fish assemblages and help to establish reasonable conservation measures.

\section{MATERIALS AND METHODS}

\section{> STUDY AREA}

The Hejiang reach selected for this study was adjacent to Hejiang County (Figure 1), Sichuan Province, about $100 \mathrm{~km}$ upstream of the backwater of the Three Gorges reservoir (175 $\mathrm{m}$ asl). The length of the study reach was about $30 \mathrm{~km}$. The width of the river varied from 500 to $1000 \mathrm{~m}$ and the water depth averaged $14.2 \mathrm{~m}$. The average annual discharge was calculated to be $2690 \times 10^{8} \mathrm{~m}^{3}$, with the flooding period usually between June and September and the dry season occurring from December to May (http://xxfb.hydroinfo.gov.cn). The substrate was composed of rock and bedrock in the main channel, with dozens of beaches studded on the windings. With the diversified habitats, the Hejiang reach was historically an important fishing ground where the traditional target species included Coreius, Rhinogobio, Pelteobagrus, Silurus and Acipenser (Dan et al., 1999). In 2005, the Chinese government authorized the foundation of "the National Reserve of the Upper Yangtze for Endangered and Endemic Fish" (NRUYEEF) in order to protect the fish resource in the upper Yangtze river; the Hejiang reach naturally became one of the core areas of the reserve (Ministry of Agriculture of the People's Republic of China 2004). As it is located in the lower reach of the reserve, the Hejiang reach was also considered as an important communication corridor for fish between the TGR and the NRUYEEF (Cao, 2000; Wu et al., 2011). Many potadromous fish (e.g. the four domestic Chinese carps, Coreius and Rhinogobio) migrate up to the NRUYEEF for reproduction during their breeding season, whereas their offspring drift down to the backwater of the TGR for feeding (Jiang et al., 2010). 


\section{> FISH SAMPLING}

Fish samplings were conducted biannually during spring (May-June) and fall (SeptemberOctober) between 1997 and 2011. Each sampling continued for about three weeks. We investigated more than ten local fishing boats using drift gillnets with meshes ranging from 3 to $5 \mathrm{~cm}(100-200 \mathrm{~m}$ long $\times 1.0-2.3 \mathrm{~m}$ high). Nine traditional fishing sites (sites 1-9) were located along the study reach with a length of $1-2 \mathrm{~km}$, representing all accessible habitat types (Figure 1). All these sites were sampled evenly each year. Normally, fish were collected during the daytime between 0600 and $1800 \mathrm{~h}$. Each fishing boat had one catch per day and most of the boats were investigated every day during the sampling period. Fish were identified, counted, measured (to the nearest $\mathrm{mm}$ ) and weighed (to the nearest $\mathrm{g}$ ).

Drift gillnets with meshes ranging from 3 to $5 \mathrm{~cm}$ may not be effective for catching small fish. Therefore, our investigations were restricted to larger-bodied species or larger size classes. Since all samplings were carried out using the same fishing gear, the collections can provide useful information of interannual changes in relative abundance of the dominant species (Gido et al., 2000).

\section{> DATA ANALYSIS}

To determine the temporal variations in species composition, the degrees of similarity of the fish assemblages among different sampling years were examined using cluster analysis (a group average hierarchical sorting strategy) and non-metric multidimensional scaling (nMDS) ordination analysis based on the Bray-Curtis similarity matrix (Clarke, 1993). Because the purpose of the analyses was to determine interannual variations in fish assemblages, the data obtained in the same year were pooled in the analyses. Relative biomass data (percentage of total biomass over all species) for each species during each year was square root-transformed in order to normalize the data and avoid skew, and the Bray-Curtis similarity coefficient was calculated based on the relative biomass matrices. Rare species whose relative biomass was less than $0.1 \%$ and occurred in less than three years were excluded from the analysis. Analysis of similarity (ANOSIM) was carried out to determine the differences among different year groups. Similarity of percentage analysis (SIMPER) was used to identify those species most responsible for the dissimilarity among different year groups.

Variation in species relative abundance was also examined by the Abundance Biomass Comparison (ABC) method (Warwick, 1986). ABC curves were constructed and the W-statistic was calculated; a negative sign indicated that the biomass curve was below the abundance curve and suggested a disturbed community, whereas a positive sign indicated that the biomass curve was above the abundance curve and showed an undisturbed state. Changes in average body size over time were explored using linear regression and size frequency distributions were also examined for the most abundant species.

All these multivariate analyses were performed with the PRIMER 5 software package (Clarke and Warwick, 1994), including the modules 'CLUSTER', 'NMDS', 'SIMPER', 'ANOSIM' and 'ABC', respectively.

\section{RESULTS}

\section{> SPECIES COMPOSITION}

Over the 15-year study period, 79 species from 47 genera and 10 families were collected by drift gillnets, corresponding to 51441 individuals, weighing $4309864.2 \mathrm{~g}$. Twenty of the recorded 79 species were endemic to the upper Yangtze River (Table I). In terms of the number of species recorded, Cyprinidae was the most abundant family (62\%), followed by Bagridae (14\%) and Cobitidae (8\%). Eleven species, Coreius heterodon, Coreius guichenoti, Rhinogobio typus, Rhinogobio typus, Rhinogobio ventralis, Rhinogobio cylindricus, Cyprinus carpio, 


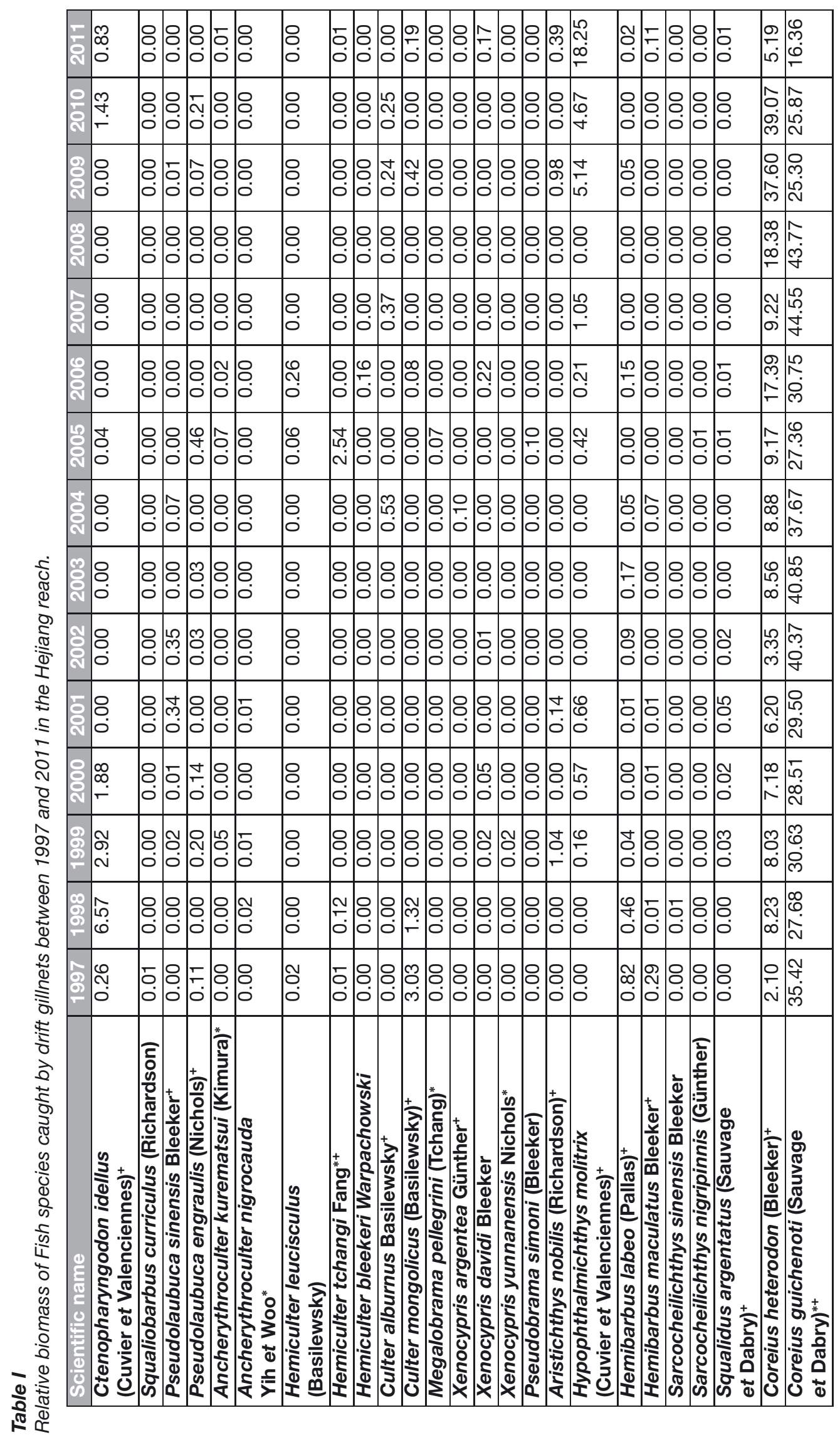




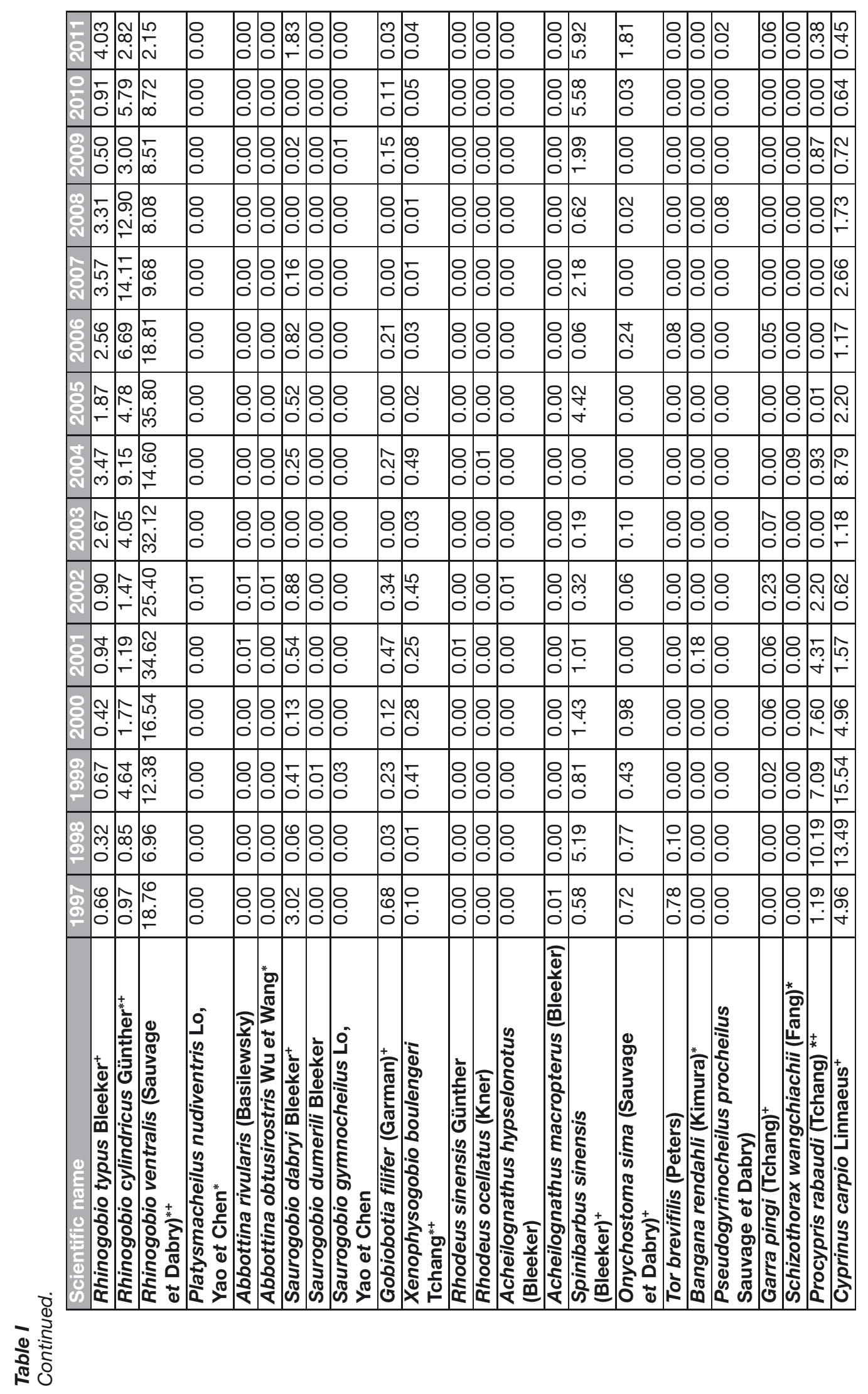




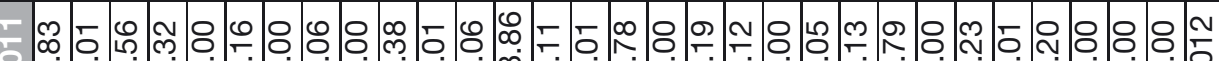
\begin{tabular}{c}
0 \\
\hdashline
\end{tabular}

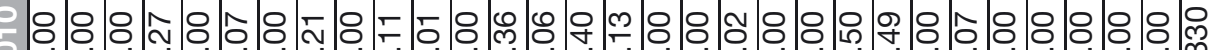

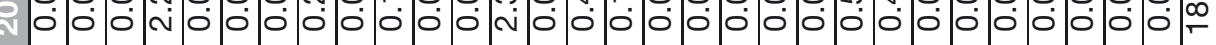

8 8 8 8

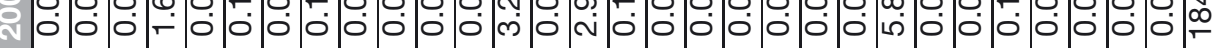
$: 8$ :

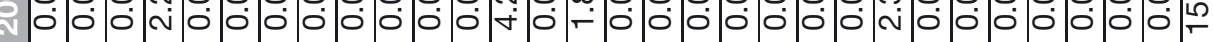
-

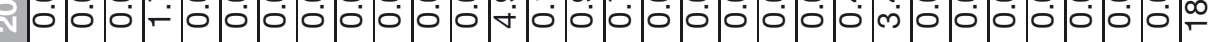

:

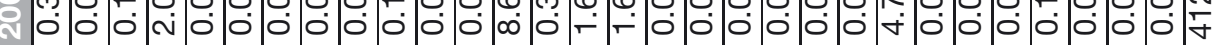
\& ล

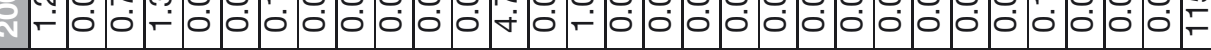

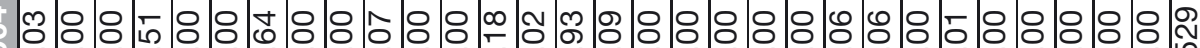

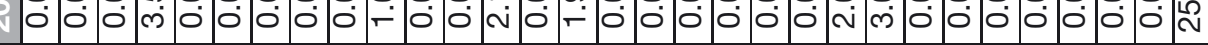

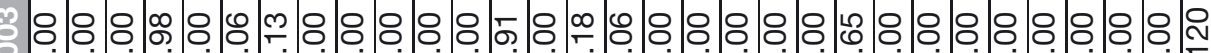

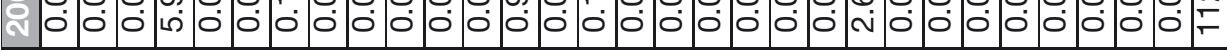
\&

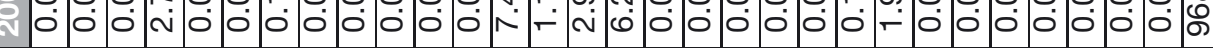
৪ ৪ ব

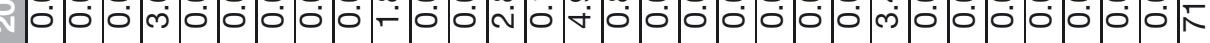
ㅇ. 우

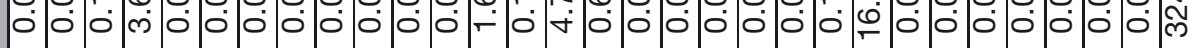

N

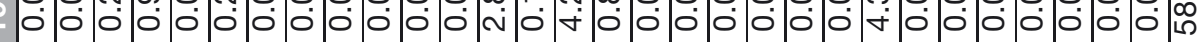
:

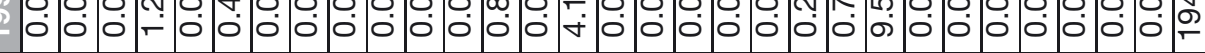

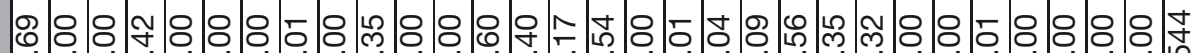

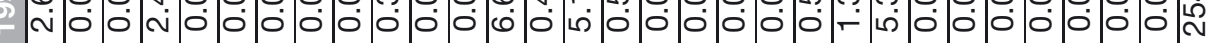

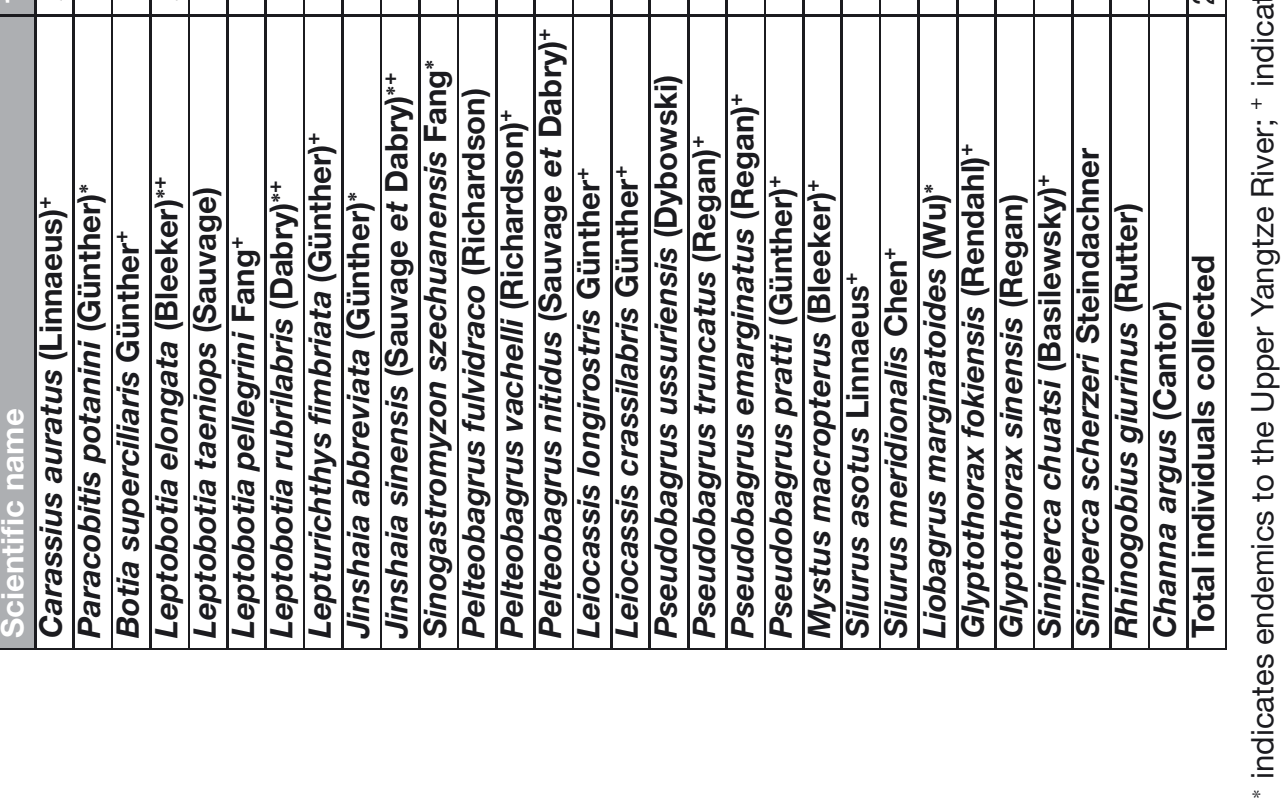




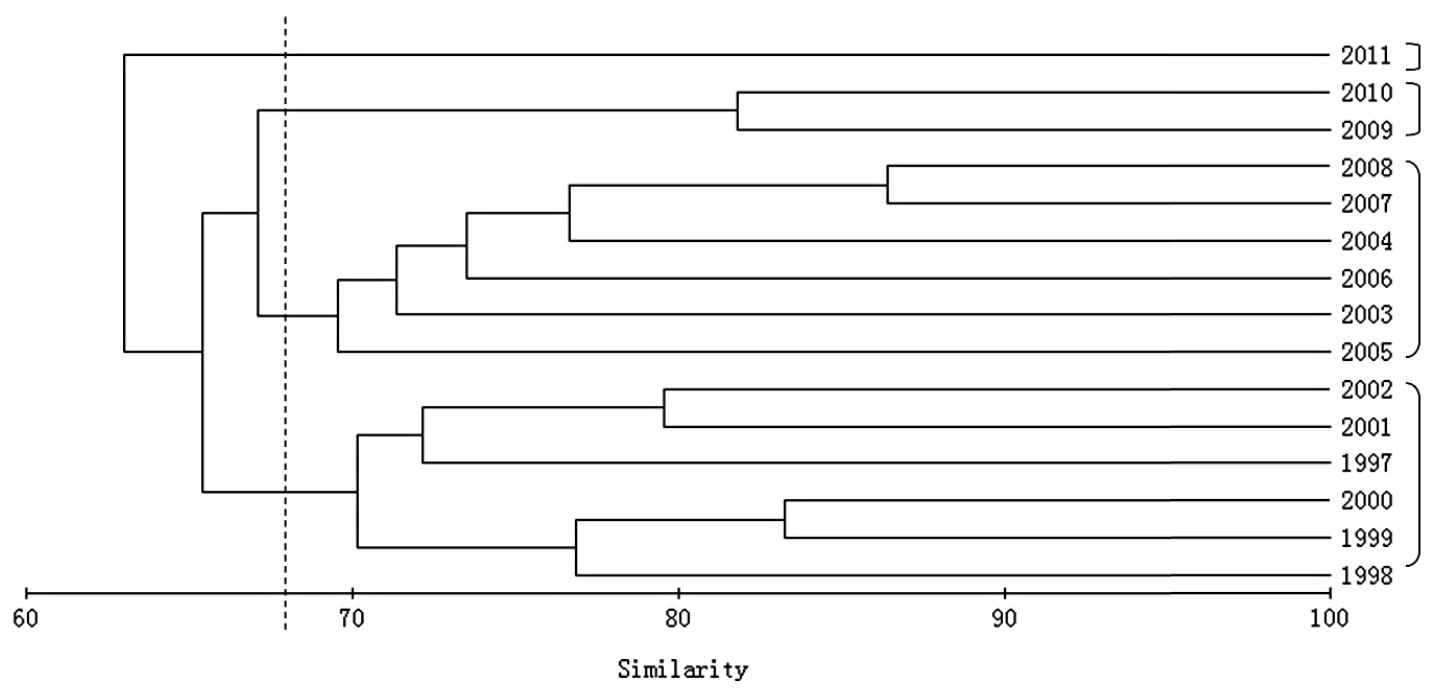

\section{Figure 2}

Classification analysis dendrogram based on Bray-Curtis similarity between samplings in Hejiang reach.

Leptobotia elongate, Pelteobagrus vachelli, Leiocassis longirostris and Leiocassis crassilabris, were observed consistently in every year and occupied a large proportion in the catches. Thirty-two species were present less than three years and relative biomass of another three species was less than $0.1 \%$; these 35 species were considered as rare species and excluded from the analysis. Consequently, 44 species were used for the further analysis.

\section{> TEMPORAL PATTERNS IN FISH ASSEMBLAGE}

Classification analysis based on drift gillnet catch data for each year in terms of species relative biomass revealed notable changes during the study period and identified four distinct sampling periods (1997-2002, 2003-2008, 2009-2010 and 2011). The splitting of these year groups accurately reflected the impounding events of the Three Gorges Reservoir. For the whole assemblage, samples were agglomerated at $69.37 \%$ similarity level in the group $1997-2002$, while they were at $73.16 \%$ and $87.95 \%$ similarity for the group 2003-2008 and group 2009-2010, respectively (Figure 2). The group 2011 was the least similar to all other groups, suggesting the fish assemblage had entered a new period.

The nMDS ordination for the whole fish assemblage showed more evident temporal differences in species composition among different sampling periods (Figure 3). The group 1997-2002 tended to occupy the central base of the plot; the group 2003-2008 fell into the lower right; the group 2009-2010 was located in the top right region and the group 2011 occupied the top left. The nMDS stress value was 0.15 , suggesting the plot accurately represented the segregation of samplings among year groups. ANOSIM further confirmed the differences in fish assemblage among year groups (global $R=0.749, p<0.001$ ).

The SIMPER analysis identified species that contributed most to the dissimilarity among different year groups. The average similarity between the group 1997-2002 and the group 2003-2008 was $35.25 \%$. Fourteen species contributed nearly $90 \%$ of the observed dissimilarity in the fish assemblages (Table II). Among the 14 species, the relative biomass of lotic species, such as $R$. ventralis, $C$. guichenoti, $R$. cylindricus and $C$. heterodon, dramatically increased with time, whereas the proportion of lentic species, such as Procypris rabaudi, Silurus meridionalis, C. carpio and L. longirostris, decreased notably (Table III).

Ten species served as discriminators between the group 2003-2008 and the group 2009-2010. Changes in those species collectively contributed about $90 \%$ towards the difference (Table II). Among the 10 species, the relative biomass of most lotic species 


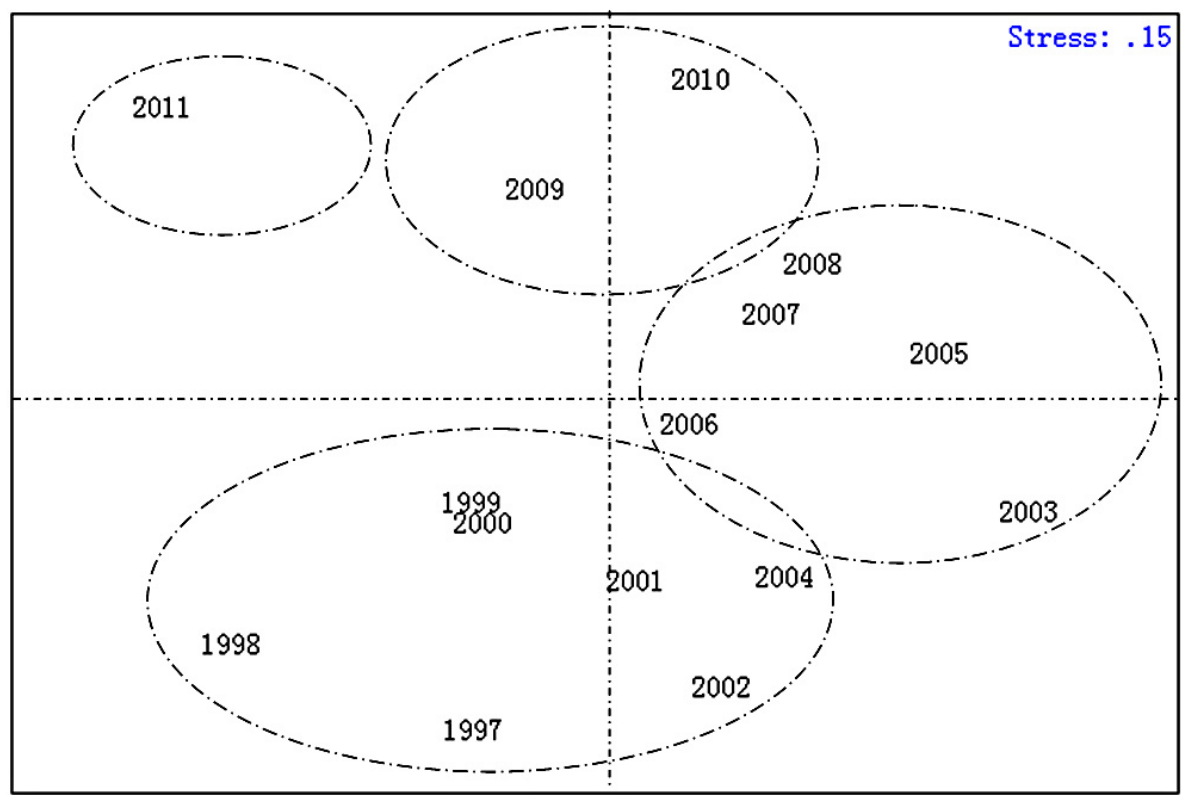

Figure 3

Multi-dimensional scaling ordination plot for the fish assemblage in Hejiang reach.

\section{Table II}

Percentage contribution (>2\%) of species to the average dissimilarity between year-groups, parenthesis indicates discriminate between groups.

\begin{tabular}{|c|c|c|c|}
\hline Species & $\begin{array}{c}1997-2002 \text { Vs. } \\
2003-2008(35.25 \%)\end{array}$ & $\begin{array}{c}2003-2008 \text { vs. } \\
2009-2010(40.20 \%)\end{array}$ & $\begin{array}{c}2009-2010 \text { vs. } \\
2011(45.87)\end{array}$ \\
\hline Rhinogobio ventralis & 15.90 & 14.20 & 5.93 \\
\hline Coreius guichenoti & 11.31 & 14.81 & 8.46 \\
\hline Rhinogobio cylindricus & 9.69 & 5.82 & \\
\hline Coreius heterodon & 8.63 & 32.84 & 30.41 \\
\hline Cyprinus carpio & 7.96 & 2.83 & \\
\hline Procypris rabaudi & 7.48 & & \\
\hline Silurus meridionalis & 6.99 & 3.50 & 2.44 \\
\hline Leiocassis longirostris & 4.37 & & 3.99 \\
\hline Pelteobagrus vachelli & 4.16 & 2.90 & 14.72 \\
\hline Rhinogobio typus & 3.20 & 2.74 & 3.05 \\
\hline Ctenopharyngodon idellus & 2.75 & & \\
\hline Spinibarbus sinensis & 2.42 & 3.70 & \\
\hline Leptobotia elongate & 2.16 & & 4.02 \\
\hline Hypophthalmichthys molitrix & & 5.75 & 12.24 \\
\hline Leiocassis crassilabris & 2.03 & & \\
\hline Summation & 89.05 & 89.09 & 85.26 \\
\hline
\end{tabular}

(e.g. C. guichenoti, R. ventralis and R. cylindricu) declined with time, while C. heterodon gained a further increase after the third impoundment and became the most dominant species. Besides, Hypophthalmichthys molitrix, a typical lacustrine species, became the second most important discriminating species with the relative biomass increased to $4.91 \%$, up from $0.28 \%$ (Table III).

Nine discriminating species collectively contributed $85.26 \%$ of the observed dissimilarity between the group 2009-2010 and the group 2011 (Table II). Among the most notable changes was the further decrease in lotic species, while lentic $P$. vachelli and $H$. molitrix increased tremendously (Table III). 
Table III

Average relative biomass and habitat type of the most contributed species (contribution $>2 \%$ ) among different year-groups.

\begin{tabular}{|l|c|c|c|c|c|}
\hline Species & $1997-2002$ & $2003-2008$ & $2009-2010$ & 2011 & Habitat guild \\
\hline Coreius guichenoti & 32.02 & 37.49 & 25.59 & 16.36 & Lotic \\
\hline Rhinogobio ventralis & 19.11 & 19.85 & 8.62 & 2.15 & Lotic \\
\hline Silurus meridionalis & 6.79 & 2.29 & 3.15 & 1.79 & Lentic \\
\hline Coreius heterodon & 5.85 & 11.93 & 38.34 & 5.19 & Lotic \\
\hline Cyprinus carpio & 6.86 & 2.96 & 0.68 & 0.45 & Lentic \\
\hline Procypris rabaudi & 5.43 & 0.16 & 0.44 & 0.38 & Lentic \\
\hline Leiocassis longirostris & 4.36 & 1.28 & 1.67 & 6.01 & Lotic \\
\hline Pelteobagrus vachelli & 3.68 & 4.30 & 2.82 & 18.86 & Lentic \\
\hline Leptobotia elongate & 2.43 & 2.81 & 1.94 & 6.32 & Lotic \\
\hline Rhinogobio cylindricus & 1.82 & 8.61 & 4.40 & 2.82 & Lotic \\
\hline Leiocassis crassilabris & 1.53 & 0.45 & 0.13 & 0.78 & Lentic \\
\hline Saurogobio dabryi & 0.84 & 0.29 & 0.01 & 1.83 & Lentic \\
\hline Ctenopharyngodon idellus & 1.94 & 0.01 & 0.72 & 0.83 & Lentic \\
\hline Spinibarbus sinensis & 1.56 & 1.25 & 3.79 & 5.92 & Lotic \\
\hline Rhinogobio typus & 0.65 & 2.91 & 0.71 & 4.03 & Lotic \\
\hline Hypophthalmichthys molitrix & 0.23 & 0.28 & 4.91 & 18.25 & Lentic \\
\hline Summation & 95.10 & 96.87 & 97.92 & 91.97 & \\
\hline
\end{tabular}

\section{Table IV}

Average standard lengths ( $\mathrm{mm} S L)( \pm S D$ ) of the six most abundant species caught by drift gillnets during study period.

\begin{tabular}{|l|c|c|c|c|c|c|}
\hline Year & C. guichenoti & C. heterodon & C. ventrallis & $R$. Gylindricus & P. vachellf & H. molitrix \\
\hline $\mathbf{1 9 9 7}$ & $176.3 \pm 26.5$ & $199.3 \pm 39.5$ & $169.2 \pm 13.0$ & $175.5 \pm 22.9$ & $149.3 \pm 46.6$ & \\
\hline $\mathbf{1 9 9 8}$ & $168.7 \pm 62.0$ & $264.1 \pm 97.6$ & $168.2 \pm 16.4$ & $189.8 \pm 20.1$ & $185.6 \pm 70.1$ & \\
\hline $\mathbf{1 9 9 9}$ & $122.0 \pm 40.6$ & $247.7 \pm 80.1$ & $143.2 \pm 31.9$ & $179.3 \pm 20.1$ & $124.5 \pm 46.0$ & 350.0 \\
\hline $\mathbf{2 0 0 0}$ & $181.2 \pm 60.9$ & $264.6 \pm 54.4$ & $174.8 \pm 22.2$ & $189.5 \pm 18.3$ & $129.7 \pm 39.5$ & $351.7 \pm 35.5$ \\
\hline $\mathbf{2 0 0 1}$ & $179.0 \pm 53.0$ & $248.3 \pm 52.6$ & $160.4 \pm 23.6$ & $195.5 \pm 18.9$ & $125.7 \pm 27.0$ & 440.0 \\
\hline $\mathbf{2 0 0 2}$ & $153.9 \pm 75.7$ & $197.0 \pm 23.7$ & $143.1 \pm 29.7$ & $180.5 \pm 19.6$ & $126.3 \pm 26.2$ & \\
\hline $\mathbf{2 0 0 3}$ & $195.1 \pm 29.6$ & $203.6 \pm 28.9$ & $173.7 \pm 18.6$ & $190.4 \pm 15.0$ & $154.3 \pm 19.3$ & \\
\hline $\mathbf{2 0 0 4}$ & $191.2 \pm 38.1$ & $237.8 \pm 55.9$ & $132.8 \pm 37.4$ & $192.7 \pm 23.1$ & $117.4 \pm 30.7$ & \\
\hline $\mathbf{2 0 0 5}$ & $202.4 \pm 38.7$ & $211.7 \pm 34.9$ & $175.3 \pm 16.0$ & $196.6 \pm 19.5$ & $143.9 \pm 50.5$ & 317.0 \\
\hline $\mathbf{2 0 0 6}$ & $165.1 \pm 36.0$ & $212.3 \pm 32.5$ & $160.0 \pm 19.1$ & $185.7 \pm 14.9$ & $139.1 \pm 42.0$ & 237.0 \\
\hline $\mathbf{2 0 0 7}$ & $184.9 \pm 37.0$ & $221.9 \pm 38.9$ & $165.8 \pm 23.0$ & $194.7 \pm 22.1$ & $140.1 \pm 34.9$ & 482.0 \\
\hline $\mathbf{2 0 0 8}$ & $208.6 \pm 29.9$ & $242.2 \pm 39.1$ & $177.2 \pm 21.2$ & $198.5 \pm 20.9$ & $170.6 \pm 46.3$ & \\
\hline $\mathbf{2 0 0 9}$ & $168.9 \pm 60.9$ & $247.2 \pm 37.1$ & $174.2 \pm 19.8$ & $191.2 \pm 21.5$ & $142.2 \pm 47.2$ & $559.8 \pm 116.9$ \\
\hline $\mathbf{2 0 1 0}$ & $194.4 \pm 36.3$ & $242.0 \pm 26.3$ & $175.9 \pm 20.0$ & $186.9 \pm 21.5$ & $183.8 \pm 59.0$ & $481.4 \pm 137.0$ \\
\hline $\mathbf{2 0 1 1}$ & $169.3 \pm 33.5$ & $189.6 \pm 25.1$ & $153.0 \pm 30.0$ & $189.9 \pm 23.9$ & $176.7 \pm 56.5$ & $575.9 \pm 238.9$ \\
\hline $\begin{array}{l}\text { Maximum } \\
\text { size record }\end{array}$ & 570 & 630 & 365 & 334 & 445 & 901 \\
\hline Statistics of linear regression & 0.137 & 0.045 & 0.028 & 0.219 & 0.122 & 0.675 \\
\hline $\boldsymbol{r}^{2}$ & 0.175 & 0.446 & 0.548 & 0.079 & 0.201 & 0.046 \\
\hline $\boldsymbol{p}$ & \multicolumn{7}{|c|}{} \\
\hline
\end{tabular}

\section{> CHANGE IN BODY SIZE DISTRIBUTION}

Five of the 6 most dominant species (C. guichenoti, C. heterodon, C. ventralis, $R$. cylindricus and $P$. vachelli) demonstrated no consistent increase or decrease trend in average standard length (Table IV). Even so, fluctuations were observed for C. guichenoti and C. heterodon, the two large-bodied lotic species, whose maximum sizes were recorded as $570 \mathrm{~mm}$ and $630 \mathrm{~mm}$, respectively. The average length of C. guichenoti was no more than $180 \mathrm{~mm}$ prior to the impoundment, which increased to $200 \mathrm{~mm}$ immediately after the first impoundment. The distribution of the size structure showed similar trends; during the period of 1997-2002, C. guichenoti individuals collected were mainly $100-150 \mathrm{~mm}$ in standard length, which increased to $200-250 \mathrm{~mm}$ after the first impoundment in 2003 (Figure 4). C. heterodon exhibited 

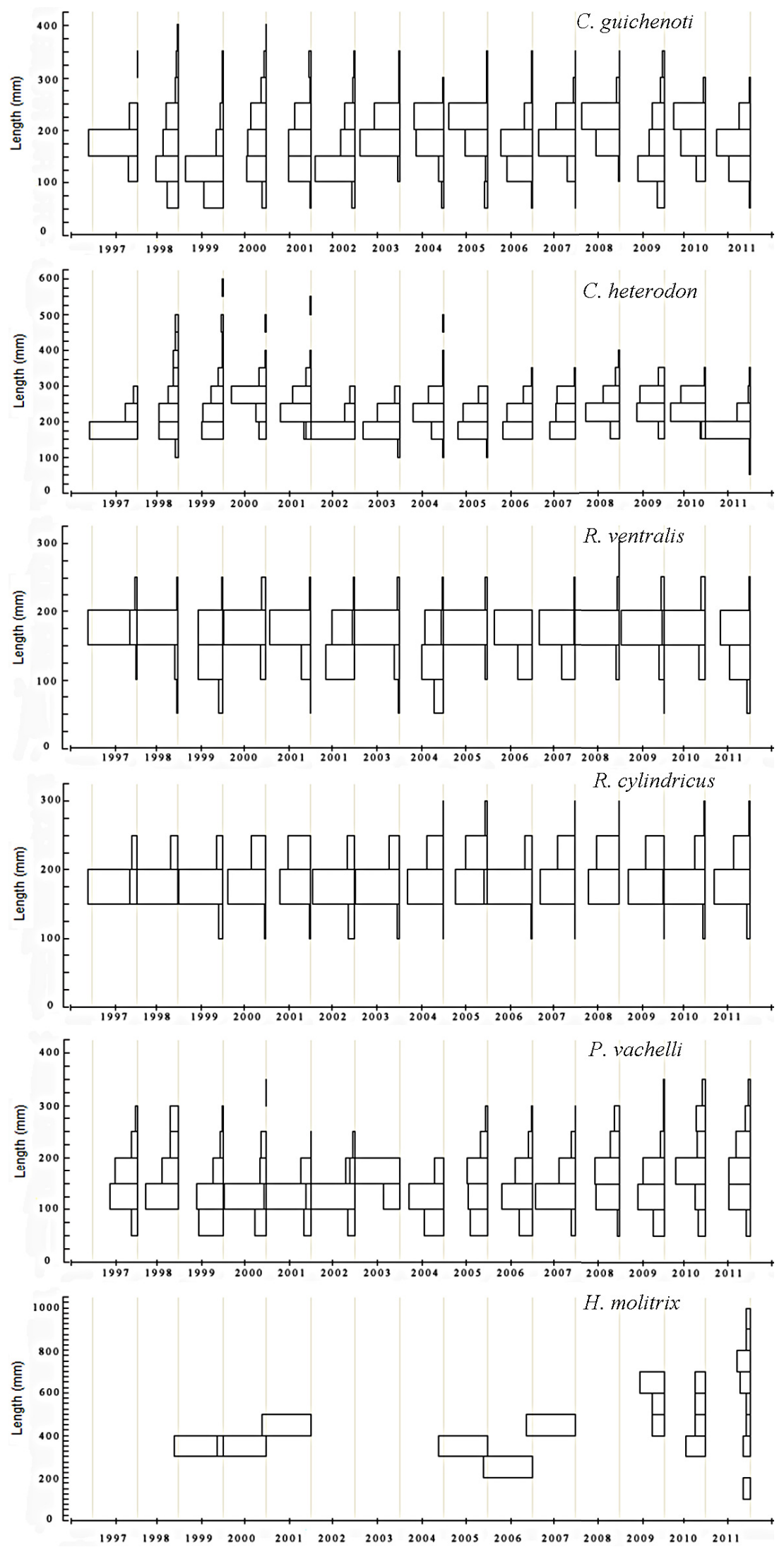

Figure 4

Temporal changes in size structure of the most dominant species during the study period. 

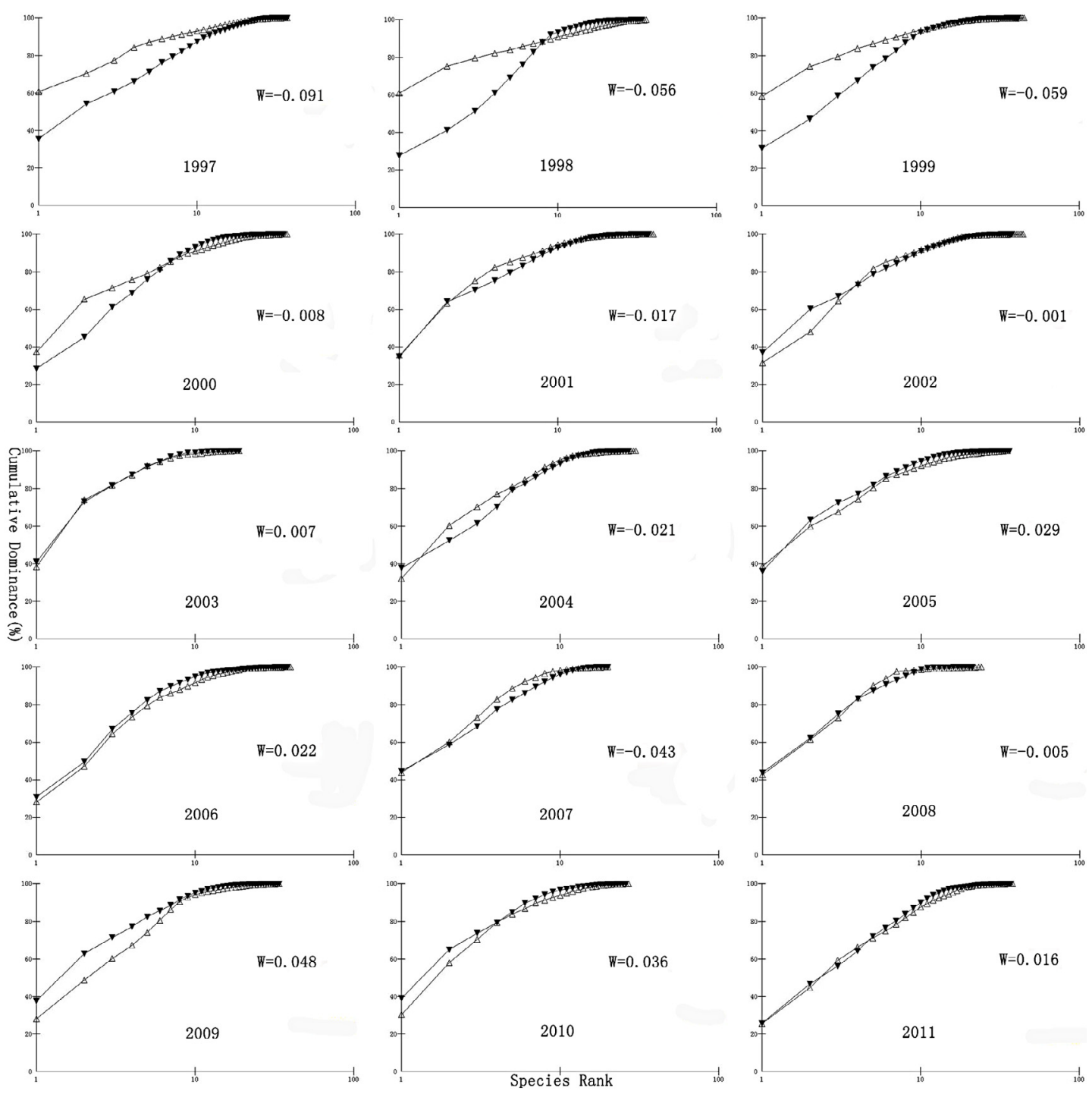

Figure 5

$A B C$ curves for the whole fish assemblages from 1997 to 2011 in Hejiang reach ( $\nabla$ biomass; $\triangle$ abundance).

a decreased trend in body size during the pre-impoundment period; however, a remarkable increase in dominant size was observed immediately after the first impoundment and a similar phenomenon was also found after the third impoundment.

$H$. molitrix, a typical lacustrine species, showed a gradually increasing body size with time (linear regression, $\left.r^{2}=0.675, p=0.046\right)$. During the period from 1997 to $2008, H$. molitrix individuals collected were $300-400 \mathrm{~mm}$ in standard length, which increased to more than $500 \mathrm{~mm}$ thereafter. At the same time, many mature individuals were caught in breeding season.

\section{> CHANGES IN ASSEMBLAGE DOMINANCE}

Differentiation among sampling years was further demonstrated by the ABC curves (Figure 5). During the pre-impoundment period (1997-2002), the biomass curves and the abundance curves crossed once or twice with negative W-statistics, which suggested the existence of stressed conditions. However, after the first impoundment in 2003, the W-statistics showed 
a trend of changes in fish assemblages from negative towards positive, which continued until 2006 (except for 2004). These changes might be caused by the upstream migration of larger individuals from the reservoir while it was filling. The suddenly increased biomass and mean body length of the dominant species, such as $C$. guichenoti and $C$. heterodon, after impoundments confirmed the influxes of larger individuals (Table IV). For 2007 and 2008, the W-statistics turned out to be negative again. However, a positive W-statistic was recorded immediately after the second impoundment, suggesting another influx of large-bodied species; C. heterodon and $H$. molitrix were the greatest contributors (Table III).

\section{DISCUSSION}

\section{> VARIATION IN FISH ASSEMBLAGE}

According to Thornton (1990), the longitudinal hydrological gradient fall along the main reservoir axis can be divided into three zones: riverine, transitional and lacustrine. Hejiang reach was still a riverine segment after the impoundment of the TGR, and the water temperature and discharge remained unaffected. Even so, multivariate analysis revealed significant temporal differences in fish assemblages and four sampling periods were identified. The splitting of these year groups accurately reflected the impounding events of the TGR. Prior to the first impoundment in 2003, the fish assemblage was diverse and even, with both lotic and lentic species occupying large proportions in catches. However, the relative biomass of lotic $C$. guichenoti, $R$. ventralis, $R$. cylindricus and $C$. heterodon increased markedly after impoundments of the TGR, while the lentic species showed an opposite trend. The increased species, Coreius and Rhinogobio, were well adapted to the swift-flowing waters and responded sensitively to the changes in flow regime. Previous studies indicated that lotic species have declined sharply in the lacustrine zone of the TGR following the impoundments. The two typical lotic species, $C$. guichenoti and C. heterodon, collectively accounted for more than $70 \%$ of the gross catch of the Wanzhou reach in the 1970 s, which decreased to $16.76 \%$ after the damming (Duan et al., 2002) and 8.46\% after the first impoundment (Wu et al., 2007). Now these lotic species have almost disappeared in the reservoir area of the TGR (Institute of Hydrobiology, unpublished data). The same phenomenon occurred in the transitional zone (Wu et al., 2007; Gao et al., 2010; Yang et al., 2012). The relative biomass of the two Coreius species was over $70 \%$ in the 1970 s in Banan reach, which declined to $46.87 \%$ in $1997-2000$ and $35.7 \%$ in 2005-2006 (Wu et al., 2007). Obviously, the lentic environment caused by the impoundment could no longer satisfy the ecological requirements of these lotic species and forced them to move upstream in order to find a suitable habitat. Therefore, we observed great influxes of lotic fish in Hejiang, a natural-flowing upper reach, immediately after the impoundments of the TGR.

We also noticed that lentic species became the new dominant species two years after the third impoundment. As one of the four domestic Chinese carps, $H$. molitrix, displayed a preference for a lacustrine environment and fed mainly on phytoplankton, the creation of the TGR provided broad spaces and abundant food resources for the development of the population. Additionally, the local governments have released a large number of fingerlings into the reservoir in order to promote the local fishery. Now $\mathrm{H}$. molitrix has become the most dominant species in reservoir areas (Wu et al., 2007). Although $H$. molitrix lives in the lacustrine zone in most of its life history, strict channel morphology and hydrological conditions are required in its reproduction phase; the sections with outcropping sharp rock and sandbars were favorable to $H$. molitrix spawning (Duan et al., 2009). After several years of growth, individuals held by the closure of the dam or released by humans have reached the age of maturity. The parent $H$. molitrix migrated upstream for spawning from the lacustrine zone during their breeding season and their spawning grounds have been found near the Hejiang reach by recent investigations (Jiang et al., 2010). This is why many matured individuals have been caught since 2009 . 


\section{>APPLICATION OF ABC METHODS}

Multivariate clustering methods, such as classification and ordination, were sensitive to changes in community structure, but they did not show exactly the direction of these changes (Yemane et al., 2005). The Abundance Biomass Comparison (ABC) method based on the classical evolutionary theory $r$ and $k$ selection was initially proposed by Warwick (1986) as a technique for monitoring disturbance of benthic invertebrate communities. It was also widely applied to detecting the fish assemblage changes in response to disturbance, such as fishing (Bianchi, 2000; Yemane et al., 2005), pollution and engineering (Penczak, 1999). In undisturbed states, the community was supposed to be dominated by $k$ selection species (slow-growing, large body size, long lifespan and late-maturing), but with increasing disturbance, the system was gradually dominated by $r$ selection species with the attributes of fast-growing, small body size and short lifespan. The ABC can reflect changes not only in relative abundance of large and small species, but also in size composition (Yemane et al., 2005). The present study is the first application of the ABC method to explore fish assemblage changes in the Upper Yangtze River, and the ABC curves and their corresponding $W$-statistic revealed remarkable temporal variations during the study period. After decades of intensive exploitation, the fishery resource in the Hejiang reach has been seriously damaged (Dan et al., 1999), and the results of ABC confirmed the existence of high stress to the fish assemblage, with the W-statistics during 1997-2002 all being negative. However, positive W-statistics were recorded immediately after the impoundments of the TGR, likely due to the influx of larger-bodied individuals from downstream. The species that considerably increased, such as $C$. guichenoti, $C$. heterodon and $H$. molitrix, were larger-bodied compared with other species; their influx would undoubtedly lead to changes in the body size structure and outweighed the impacts caused by fishing. The large influx of recruits of dominant species can seriously affect the results of ABC analysis, which was also observed by Penczak (1998) and Yemane et al. (2005). In this study, we did not examine fish movements (e.g., telemetry and mark-recapture). However, we can infer that fish migrations likely have happened based on the fish assemblage changes in our study reach combined with other research in the lacustrine zone and transitional zone of the TGR.

\section{>PREDICTION OF FUTURE FISH ASSEMBLAGE CHANGES IN THE UPPER YANGTZE RIVER}

The upper Yangtze River basin harbors 286 fish species, representing the highest biodiversity of the Palearctic region (Nelson, 1994; Matthews, 1998). The fish fauna is characterized by a high degree of endemism ((Park et al., 2003; He et al., 2011). These endemic species have evolved life history strategies primarily in direct response to the natural flow regimes (Cao, 2000). Based on this and other studies, we can see that the habitat of riverine fish has been seriously shrunk due to the impoundments of the TGR (Wu et al., 2007; Gao et al., 2010; Yang et al., 2012). Many lotic species were forced to move upstream and congregated into the limited fluvial upstream stretch, which exposed them to intensive exploitation and frequent natural or human-induced catastrophic events. However, the aquatic environment in the upper Yangtze River will continue changing. According to planning, four large hydropower stations (Xiangjiaba, Xiluodu, Baihetan and Wudongde) are being or will be established in the lower Jinsha River. Fishes in the upper Yangtze River will be subjected to irreversible and accumulative effects from these cascade reservoirs. $C$. guichenoti and $R$. ventralis will be the first victims because their spawning grounds are distributed exclusively in the Jinsha River and Yalong River (Liu et al., 1990). However, their migratory routes were blocked with the closure of the Xiangjiaba hydropower station in 2008. By now, spawning grounds of $C$. guichenoti and $R$. ventralis are not found below the Xiangjiaba Dam. Other species, such as $C$. heterodon, $R$. cylindricus and $L$. elongate, will also be seriously effected by the cascade hydropower development in the upper reaches because their entire life cycles are completed within the river system and require particular habitats and rigorous environmental cues (e.g., temperature, 
flow regime, substrate) to fulfill the reproductive process (Liu et al., 1990). The altered flow regime and water temperature will greatly change their habitat or probably lead to failure in reproduction. It is expected that species with specific ecological requirements will decrease sharply in the upper Yangtze River. On the other hand, Hemiculter, Pelteobagrus and other species with simpler biological demands or great reproductive plasticity will became the dominant species.

\section{> SUGGESTIONS FOR CONSERVATION}

In order to protect the fish resource in the upper Yangtze River, the Chinese government authorized the foundation of "the National Reserve of the Upper Yangtze for Endangered and Endemic Fish" (NRUYEEF) in 2005. The reserve is now the largest aquatic reserve in China, comprising the mainstream of the Yangtze River from Xiangjiaba Dam to Mashaxi, the mainstream of the Chishui River and some of its tributaries, the lower Minjiang River and its tributary Yuexi River, and the estuaries of the Nanguang River, Changning River, Tuojiang River and the Yongning River (Ministry of Agriculture of the People's Republic of China, 2004). The reserve aims at preserving three rare fish (Psephurue gladius, Acipenser dabryanus and Myxocyprinus asiaticus) and another 66 endemic fish and their essential habitats. Our study demonstrated that many lotic species likely migrated up into the NRUYEEF for escape from the adverse effects caused by the impoundments of the TGR. Furthermore, lentic species such as $H$. molitrix use this fluvial upstream stretch as spawning ground. We must realize the importance of this corridor for fish conservation and keep the stretch between the backwater of the TGR and NRUYEEF unimpeded. Considering that the aquatic environment in the mainstream of the upper Yangtze River will be seriously affected by the cascade hydropower development in the lower Jinsha River, long-term monitoring, research and mitigation measures should be intensified. As the function of the mainstream of the NRUYEEF will be undermined, it is necessary to strengthen the protection of the Chishui River, the last undammed tributary of the upper Yangtze River (Wu et al., 2011).

\section{ACKNOWLEDGEMENTS}

This paper is the result of many years of field investigations. We are grateful to Shengguo Dan, Taiming Yan and other colleagues for their assistance in the collection of data. Thanks are given to Huanzhang Liu, Jinming Wu and Mingzheng Li for their constructive comments on the manuscript drafts. This study was funded by the National Key Technology R\&D Program (2008BAC39B03), the Three Gorges Project Eco-Environmental Monitoring System (JJ [2011]028) and the National Natural Science Foundation of China (NSFC 31061160185).

\section{REFERENCES}

Agostinho A.A., Pelicice F.M. and Gomes L.C., 2008. Dams and the fish fauna of the Neotropical region: impacts and management related to diversity and fisheries. Braz. J. Biol. 68, 1119-1132.

Bianchi G., Gislason H., Graham K., Hill L., Jin X., Koranteng K., Manickchand-Heileman S., Payà I., Sainsbury K., Sanchez F. and Zwanenburg K., 2000. Impact of fishing on size composition and diversity of demersal fish communities. J. Mar. Sci., 57, 558-571.

Bunn S.E. and Arthington A.H, 2002. Basic principles and ecological consequences of altered flow regimes for aquatic biodiversity. Environmental Management, 30, 492-507.

Cao W.X., 2000. The natural reserve construction of endemic fishes in the upper Yangtze River and its related problems. Resources and environment in the Yangtze Basin, 9, 131-132 (in Chinese).

Cao W.X., 2008. Several issues concerning protection of the Yangtze River Basin fish resources. Resources and environment in the Yangtze Basin, 17, 163-164 (in Chinese). 
Chen D.Q., Xiong F., Wang K. and Chang Y.H., 2009. Status of research on Yangtze fish biology and fisheries. Environ. Biol. Fish., 85, 337-357.

Clarke K.R., 1993. Non-parametric multivariate analyses of changes in community structure. Aust. J. Ecol., 18, 117-143.

Clarke K.R. and Warwick R.M., 1994. Changes in marine communities: an approach to statistical analysis and interpretation. Plymouth Marine Laboratory, Plymouth.

Dan S.G., Zhang G.H., Miao Z.G. and Deng X., 1999. A survey on the commercial trammel net fishery in the upper reaches of the Yangtze River. Acta Hydrobiological Sinica, 23, 655-661 (in Chinese).

Duan X.B., Liu S.P., Huang M.G., Qiu S.L., Li Z.H. Wang K. and Chen D.Q., 2009. Changes in the abundance of the larvae of the four domestic Chinese carps in the middle reach of the Yangtze River, China, before and after closing of the Three Gorges Dam. Environ. Biol. Fish., 86, 13-22.

Erman D.C., 1973. Upstream changes in fish populations following impoundment of Sagehen Creek, California. Trans. Am. Fish. Soc., 102, 626-629.

Fu C.Z., Wu J.H., Chen J.K., Wu Q.H. and Lei G.C., 2003. Freshwater fish biodiversity in the Yangtze River basin of China: patterns, threats and conservation. Biodiversity and Conservation, 12, 1649-1685.

Gao X., Zeng Y., Wang W.J. and Liu H.Z., 2010. Immediate impacts of the second impoundment on fish communities in the Three Gorges Reservoir. Environ. Biol. Fish, 87, 163-173.

Gido K.B., Matthews W.J. and Wolfinbarger W.C., 2000. Long-term changes in a reservoir fish assemblage: stability in an unpredictable environment. Ecol. Appl., 10, 1517-1529.

Gido K.B., Guy C.S., Strakosh T.R., Bernot R.J., Hase K.J. and Shaw M.A., 2002. Long-term changes in the fish assemblages of the Big Blue River basin 40 years after the construction of Tuttle Creek Reservoir. Trans. Kansas Acad. Sci., 105, 193-208.

Han M., Fukushima M., Kameyama S., Fukushima T. and Matsushita B., 2008. How do dams affect freshwater fish distribution in Japan? Statistical analysis of native and nonnative species with various life histories. Ecol. Res., 23, 735-743.

He Y.F., Wang J.W., Lek S., CAO W.X. and Lek-Ang S., 2011. Structure of endemic fish assemblage in the upper Yangtze River Basin. River Res. Appli., 27, 59-75.

Huang Z., Li Y., Chen Y., Li J., Xing Z., Ye M., Li J., Lu P., Li C. and Zhou X., 2006. Water quality prediction and water environmental carrying capacity calculation for Three Gorges Reservoir. China Water Power Press, Beijing (in Chinese).

Jiang W., Liu H.Z., Duan Z.H. and Cao W.X., 2010. Seasonal variation in drifting eggs and larvae in the upper Yangtze, China. Zool. Sci., 27, 402-409.

Johnson P.T.J., Olden J.D. and Zanden M.J.V., 2008. Dam invaders: impoundments facilitate biological invasions into freshwaters. Front. Ecol. Environ., 6, 357-363.

Larinier M., 2000. Dams and fish migration. World Commission on Dams, Toulouse, France.

Liu L.H., Wu G.X. and Wang Z.L., 1990. Reproduction ecology of Coreius heterodon (Bleeker) and Coreius guichenoti (Sauvage et Dabry) in the mainstream of the Changjiang River after the construction of Gezhouba Dam. Acta Hydrobiological Sinica, 14, 205-215 (in Chinese).

Ministry of Agriculture of the People's Republic of China, 2004. Survey Report on the National Reserve of the Upper Yangtze for Endangered and Endemic Fishes (in Chinese).

Moyle P.B. and Leidy R.A., 1992. Loss of biodiversity in aquatic ecosystems: evidence from fish faunas. In: Fiedler P.L. and Jain S.K. (eds.) Conservation biology: the theory and practice of nature conservation, preservation and management. Chapman and Hall, New York, pp. 127-169.

Nelson J.S., 1994. Fishes of the world. Wiley, New York.

Park Y.S., Chang J.B., Lek S., Cao W.X. and Brosse S., 2003. Conservation strategies for endemic fish species threatened by the Three Gorges Dam. Conservation Biology, 17, 1748-1758.

Penczak T. and Kruk A., 1999. Application of the abundance/biomass comparison method for detecting human impacts on fish population in the Pilica River, Poland. Fish. Res., 39, 229-240.

Penczak T., Glowacki L., Galicka W. and Koszali'nski H., 1998. A long-term study (1985-1995) of fish population in the impounded Warta River, Poland. Hydrobiologia, 368, 157-173.

Quinn J.W. and Kwak T.J., 2003. Fish assemblage changes in an Ozark river after impoundment: a longterm perspective. Trans. Am. Fish. Soc., 132, 110-119. 
Quist M.C., Hubert W.A. and Rahel F.J., 2005. Fish assemblage structure following impoundment of a Great Plains river. Western North American Naturalist, 65, 53-63.

Reid S.M., 2004. Post-impoundment changes to the Speed River fish assemblage. Canadian Water Resources Journal, 29, 183-194.

Thornton K.W., Kimmel B.L. and Payne F.E., 1990. Reservoir limnology: Ecological perspectives. John Wiley, New York.

Warwick R.M., 1986. A new method for detecting pollution effects on marine macrobenthic communities. Mar. Biol., 92, 557-562.

Winston M.R., Taylor C.M. and Pigg J., 1991. Upstream extirpation of four minnow species due to damming of a prairie stream. Trans. Am. Fish. Soc., 120, 98-105.

Wu J., Wang J., He Y. and Cao W., 2011. Fish assemblage structure in the Chishui River, a protected tributary of the Yangtze River. Knowl. Managt. Aquatic Ecosyst., 400, 11.

Wu Q., Duan X.B., Xu S.Y., Xiong C.X. and Chen D.Q., 2007. Studies on fishery resources in the three Gorges Reservoir of the Yangtze River. Freshwater Fisheries, 37, 70-75 (in Chinese).

Yang S.R., Gao X., Li M.Z., Ma B.S. and Liu H.Z., 2012. Interannual variations of the fish assemblage in the transitional zone of the Three Gorges Reservoir: persistence and stability. Environ. Biol. Fish., 93, 295-304.

Yemane D., Field J.G. and Leslie R.W., 2005. Exploring the effects of fishing on fish assemblages using Abundance Biomass Comparison (ABC) curves. J. Mar. Sci., 62, 374-379. 